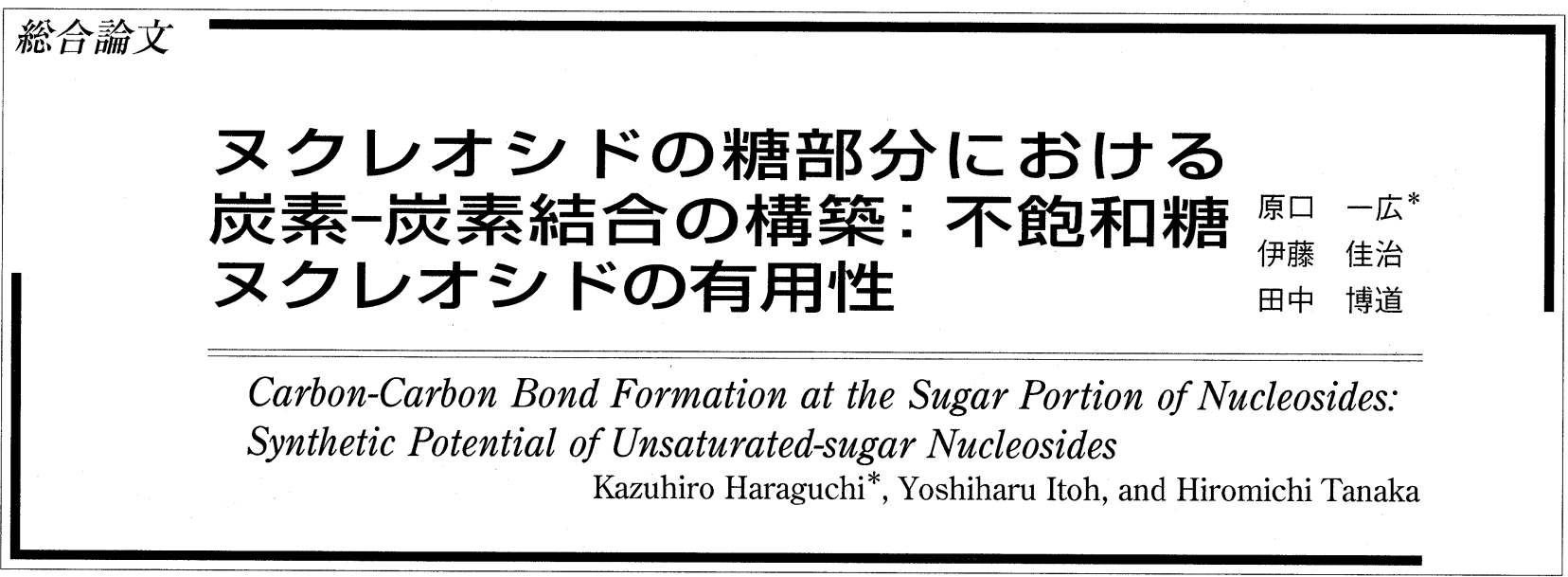

Unsaturated-sugar nucleosides have been shown to serve as versatile substrates for constructing $\mathrm{C}-\mathrm{C}$ bond at the sugar portion. Various types of appropriate reactions were adopted to $1^{\prime}, 2^{\prime}-$, $2^{\prime}, 3^{\prime}-, 3^{\prime}, 4^{\prime}-$, and $4^{\prime}, 5^{\prime}$-unsaturated derivatives. These are electrophilic addition followed by substitution with organosilicon and organoaluminum reagents, radical-mediated 1,2-acyloxy migration of the adducts, nucleophilic addition of benzenethiolate followed by radical substitution, aldol reaction of an enol ester, $\mathrm{Pd}$-catalyzed cross-coupling and halogen-lithium exchange reactions of nucleosidic vinyl bromides, $\mathrm{S}_{\mathrm{N}} 2^{\prime}$ reaction, addition reaction of carbon radicals, and epoxide ring opening with organometallic reagents. Consequently, $\mathrm{C}-\mathrm{C}$ bond formation at the $1^{\prime}-, 2^{\prime}-, 3^{\prime}-, 4^{\prime}-$, and $5^{\prime}$-positions of nucleoside became possible.

Key words: nucleoside, unsaturated sugar, carbon-carbon bond formation, organometallic reagent, electrophilic addition, nucleophilic addition, nucleophilic substitution, radical reaction, palladium-catalyzed cross-coupling, halogen-lithium exchange reaction.

はじめに

核酸の構成単位であるヌクレオシドの糖部フラノース 環上に新たな置換基が導入された糖部修飾型ヌクレオシ ドは，様々な生物活性を示すことが知られている1)。又 クレオシドの糖部分にへテロ原子を導入するには，求核 置換反応や求電子付加反応を利用できるが，炭素官能基 を導入する目的には, 糖部分の水酸基を酸化して得られ るアルデヒドやケト体に対する炭素求核剤の 1,2-付加 反応やWittig 反応が主として用いられてきた。

筆者らは，核酸有機化学の領域において炭素-炭素結 合形成反応には，ほとんど利用されることのなかった不 飽和糖ヌクレオシド (図 1, ウラシル誘導体で例示 ${ }^{2)}$ に 着目し, 糖部二重結合の多彩な反応性を利用する新規な 炭素鎖導入法の開発研究を進めてきた。不飽和糖ヌクレ オシドを基質とするアニオンの化学については，すでに 昨年の本誌で紹介した ${ }^{3)}$ 。本稿では, 求電子付加反応と 引き続く有機金属試剤の反応，ラジカル反応， $\mathrm{S}_{\mathrm{N}} 2^{\prime}$ 反 応，エポキシ環の開裂反応などを用いる糖部分への炭素 鎖導入法について述べる。

* 昭和大学薬学部薬品製造化学

* School of Pharmaceutical Sciences, Showa University

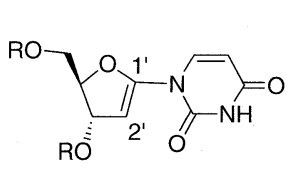<smiles>O=C1C=CC2C(CO)CCC12</smiles><smiles></smiles><smiles>O=C1OC(n2ccc(=O)[nH]c2=O)C(O)C1[Hg]</smiles>

$R=$ protecting group

Fig. 1

1. $1^{\prime}, 2^{\prime}$-不飽和ヌクレオシドの化学変換

1.1 面選択的求電子付加一求核置換反応を用いる 1'-炭素置換ヌクレオシドの合成 ${ }^{4)}$

ヌクレオシド系抗生物質 angustmycin C (図 2) ${ }^{5)}$ の発 見が契機となり，1'位に炭素置換基を有するヌクレオ シド誘導体の合成が報告されてきた。従来の合成法はあ らかじめ 1 位炭素置換糖誘導体を調製し核酸塩基と縮合 させるもので，種々の塩基を有する化合物を合成できる 反面， $1^{\prime}$ 位炭素官能基の多様性に問題を残していた。 筆者らは，1',2'-不飽和ヌクレオシドに対する求電子付 加反応によって 1'位に脱離基を導入し, 引き続き炭素 
<smiles>Nc1ncnc2c1ncn2[C@@]1(CO)O[C](CO)[C@H](O)[C@H]1O</smiles>

Fig. 2

求核剤との置換反応を行う合成経路を立案した。この反 応によって立体選択的に $\beta$-ヌクレオシドを合成する(炭 素求核剤を $1^{\prime}$ 位 $\alpha$ 側から反応させる)ためには，2'位 $\beta$ 側からの隣接基関与が必要になる。

$1^{\prime}, 2^{\prime}$-不飽和ウラシルヌクレオシド 1 とピバリン酸 トリエチルアミン／N-ブロモコハク酸イミド(NBS) と を反応させたところ，望みの立体化学を持つ付加体 2 を anti/syn $=99 / 1, \beta / \alpha=4.9 / 1$ の立体選択性で得ること ができた(スキーム 1)。反応系からトリエチルアミンを 除くと，ピバリン酸の求核性が低下してオキソニウム中 間体が介在するために，syn-付加体が優位に生成する。 またピバリン酸の代わりに酢酸を用いると付加体は不安 定であり，単離の過程でウラシルと2-ブロモ-2-デオキ シリボノラクトンに分解する。鍵中間体 2 は, 反応混合 物をショートカラムで粗精製したのち，結晶化によって 単離することができる。

$1^{\prime}$ 位における求核置換反応にはシリコン試剤および アルミニウム試剂を用いた。表 1 には，その結果をまと めてある。アリル化の場合にはシクロ体 4(25\%) が副生 するが，いずれの反応においても $\beta$-ヌクレオシド 30 みが生成し，筆者らの期待したとおり $2^{\prime}$ 位臭素原子の 隣接基関与が有効に機能していることを示している。

1.2 1,2-アシルオキシ転位によるアノメリックラジ カルの生成：1'-炭素置換アラビノフラノシル ヌクレオシドの合成 ${ }^{6)}$

先に得られた付加体 2 の脱ブロモ化を目的として, ベ ンゼン中, $\mathrm{AIBN}$ の存在下, $\mathrm{Bu}_{3} \mathrm{SnH}$ によるラジカル還

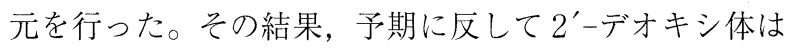

Table 1 Reaction of 2 with organosilicon and organoaluminum reagents.

\begin{tabular}{cccc}
\hline entry & reagent & $\mathrm{Nu}$ in 3 & yield of 3 \\
\hline 1 & $\mathrm{Me}_{3} \mathrm{SiCH}_{2} \mathrm{CH}=\mathrm{CH}_{2} / \mathrm{SnCl}_{4}$ & $\mathrm{CH}_{2} \mathrm{CH}=\mathrm{CH}_{2}$ & $65 \%$ \\
2 & $\mathrm{Me}_{3} \mathrm{SiCN} / \mathrm{SnCl}_{4}$ & $\mathrm{CN}$ & $80 \%$ \\
3 & $\mathrm{Ph}\left(\mathrm{OSiMe}_{3}\right) \mathrm{CH}=\mathrm{CH}_{2} / \mathrm{SnCl}_{4}$ & $\mathrm{CH}_{2} \mathrm{COPh}$ & $69 \%$ \\
4 & $\mathrm{Me}\left(\mathrm{OSiMe}_{3}\right) \mathrm{CH}=\mathrm{CH}_{2} / \mathrm{SnCl}_{4}$ & $\mathrm{CH}_{2} \mathrm{COMe}$ & $30 \%$ \\
5 & $\mathrm{Me}_{3} \mathrm{Al}$ & $\mathrm{Me}$ & $73 \%$ \\
6 & $\mathrm{Et}_{3} \mathrm{Al}$ & $\mathrm{Et}$ & $59 \%$ \\
7 & $\mathrm{Me}_{3} \mathrm{SiC} \equiv \mathrm{CAIEtCl}$ & $\mathrm{C} \equiv \mathrm{CSiMe}$ & $76 \%$ \\
\hline
\end{tabular}

得られず， $\alpha$-ウリジン誘導体 5 とウリジン誘導体 6(5/6 $=10 / 1.3)$ の混合物が得られた。この事実は，初期に生 成した $2^{\prime}$-炭素ラジカルAから 1,2-アシルオキシ転位を 経て，アノメリックラジカルBが生成したことを示して いる(スキーム 2)。そこで，アノメリックラジカルとア クセプターとの反応による $1^{\prime}$ 位での炭素-炭素結合形成 反応について検討した。

スキーム 2 の反応によって $\alpha$-ウリジン 5 が主生成物 となった事実は，B と $\mathrm{Bu}_{3} \mathrm{SnH}$ との反応における立体化 学が2'-O-ピバロイル基の立体配置によって支配されて いることを示唆している。従って $\beta$-ヌクレオシドを立 体選択的に得るためには，1'位および $2^{\prime}$ 位の立体配置 が 2 とは逆の付加体が必要となる。糖部 $3^{\prime}, 5^{\prime}$ 位の水酸 基を(ジ-tert-ブチル)シリレン基で保護した $1^{\prime}, 2^{\prime}$-不飽 和ウリジンを，ブロモーピバロイルオキシ化すると望み の立体化学を持つ $\alpha$-anti-付加体 7 のを得ることがで きるが，リジッドな環状構造のために 1,2-アシルオキ シ転位の効率が悪い。よりフレキシブルな $1,1,3,3-テ$ トライソプロピルジシロキサン-1.3-ジイル基でも $\alpha$-anti-付加体 8 が選択的に得られたので, このものを 基質として採用した。

アリルトリブチルスズ，3-ブロモ-2-メチルアクリロ

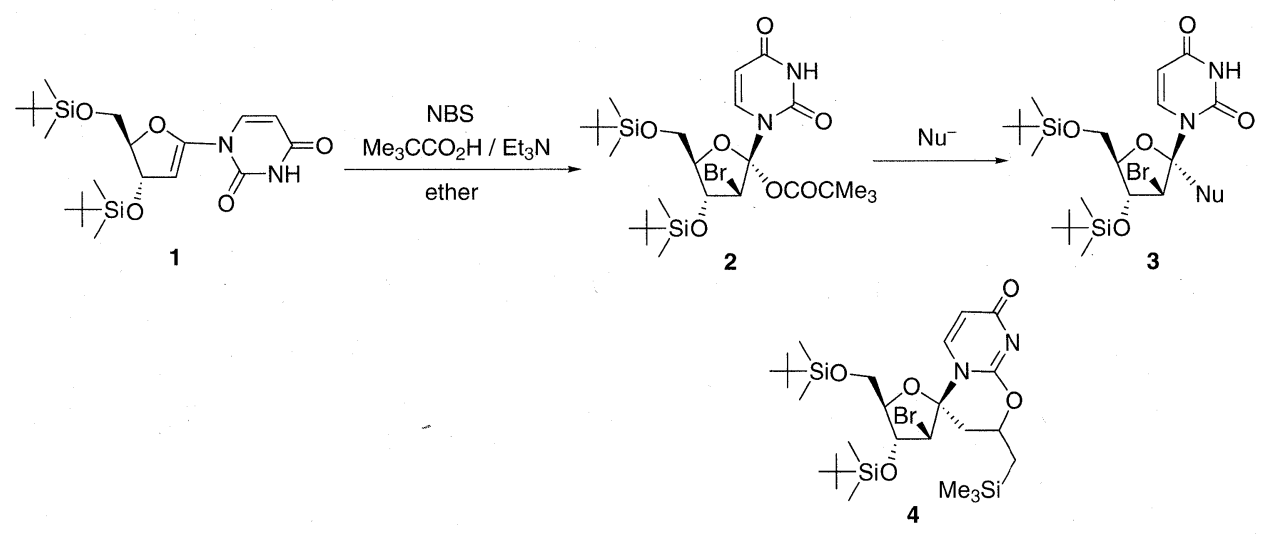

Scheme 1 


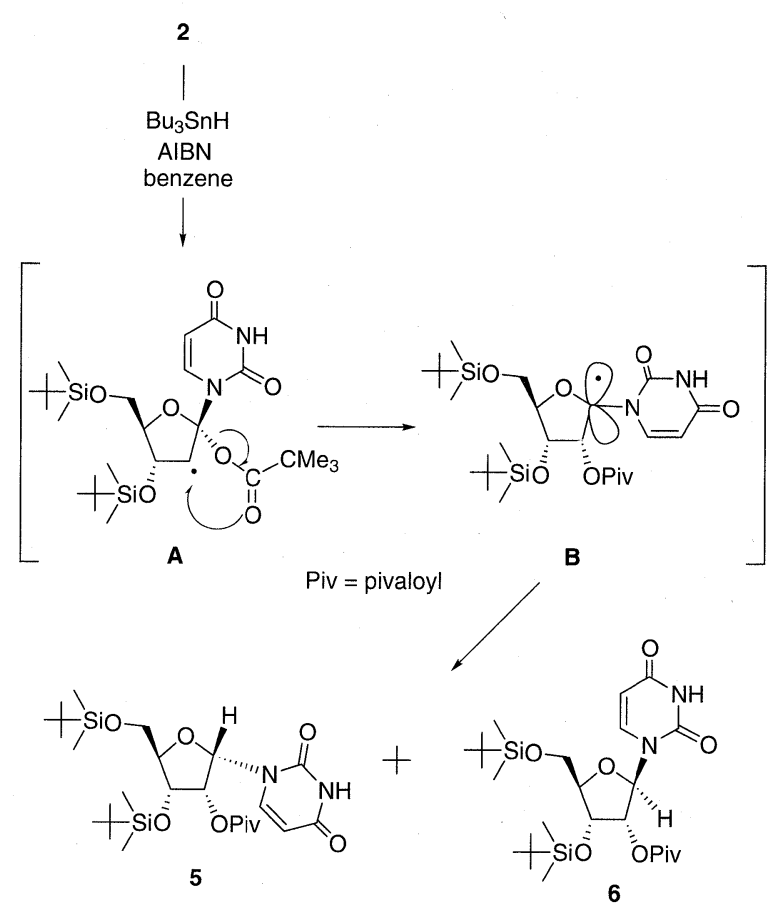

Scheme 2
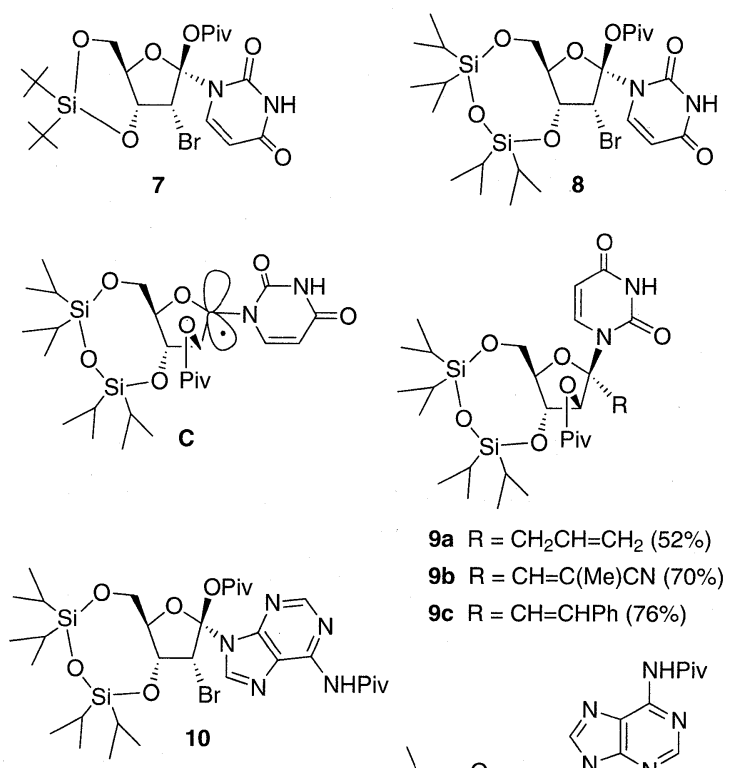

9a $\mathrm{R}=\mathrm{CH}_{2} \mathrm{CH}=\mathrm{CH}_{2}(52 \%)$

9b $\mathrm{R}=\mathrm{CH}=\mathrm{C}(\mathrm{Me}) \mathrm{CN}(70 \%)$

9c $\mathrm{R}=\mathrm{CH}=\mathrm{CHPh}(76 \%)$

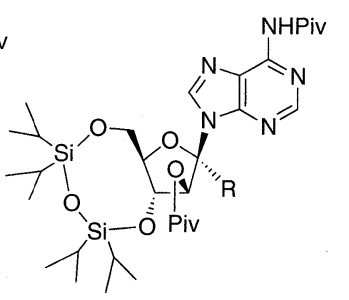

11a $\mathrm{R}=\mathrm{CH}_{2} \mathrm{CH}=\mathrm{CH}_{2}(60 \%)$. 11b $\mathrm{R}=\mathrm{CH}=\mathrm{C}(\mathrm{Me}) \mathrm{CN}(65 \%)$ 11c $\mathrm{R}=\mathrm{CH}=\mathrm{CHPh}(73 \%)$

Fig. 3

ニトリル， $\beta-($ トリブチルスタニル) スチレンなどのア クセプターの共存下に 8 のラジカル反応を行うと, アノ メリックラジカルCを経由して目的とする 1'-炭素置換 アラビノフラノシルウラシル 9a-c を立体選択的に合成 することができた(図 3)。

上記の求電子付加および付加体のラジカル反応は,
1',2'-不飽和アデニンヌクレオシドにも用いることがで き， $\alpha$-anti-付加体 10 とラジカルアクセプターとの反応 によって 1 - - 炭素置換アラビノフラノシルアデニン 11a-cを合成した。

\subsection{1',2'-不飽和ヌクレオシドに対するベンゼンチ オールの求核付加 ${ }^{7)}$}

2'-デオキシヌクレオシドの 1'位にラジカルを発生さ せるための基質としては，1'-ピバロイル体 $12^{8)}$ が知ら れていたが(図4), その合成には多工程を要した。筆者 らは，1',2'-不飽和ヌクレオシドにベンゼンチオールを 付加させることにより簡便にラジカル前駆体が合成でき ると考えた。<smiles>CC(C)(C)C(=O)[C@]1(n2ccc(=O)[nH]c2=O)C[C@H](O)[C@@H](CO)O1</smiles><smiles>CC(C)(C)O[Si](C)(C)C[Si](C)(C)C</smiles><smiles>CC(C)(C)OCC1O[C@](Sc2ccccc2)(n2ccc(=O)[nH]c2=O)C[C@@H]1OC(C)(C)C</smiles>

Fig. 4

3,4-ジヒドロ- $2 H$-ピランに対して塩化水素の存在下 にベンゼンチオールを反応させると, 求電子付加が起こ るが9，酸性条件で不安定な $1^{\prime}, 2^{\prime}$-不飽和ヌクレオシド にこの方法は適用できない。事実， $1^{\prime}, 2^{\prime}$-不飽和ウラシ ルヌクレオシド 1 とベンゼンチオールとの反応を酸触媒 の添加なしに行っても，フラン誘導体 13 が生成してく る。この反応では付加体 14 も得られるが，原料の消失 には 5 日間を要し収率もかんばしくない。

反応系にトリエチルアミンを添加すると，1 時間で反 応は完結し， $94 \%$ の収率で $14(\alpha / \beta=85 / 15)$ を単離でき た。種々のパラ置換ベンゼンチオールを用いてこの付加 反応の速度を比較してみると, 酸性度の高いチオールほ ど速やかに付加することがわかった。化合物 1 のUV吸 収極大がウリジン誘導体よりも $14 \mathrm{~nm}$ も長波長側にあ ることから, ウラシル環とフラノイドグリカール部分が 同一平面上に位置するコンホメーションを取っているこ とが予想される。従って, 1 が1a との共鳴混成体とし て存在することが(図 5), 1'位へのベンゼンチオレート の求核攻撃を可能にしているものと推定している。ウラ シル塩基 6 位または糖部 $2^{\prime}$ 位にメチル基を有する 15 や 16(図6)では，1のような UV 吸収極大の長波長シフト は認められず，これらの化合物ではベンゼンチオレート が反応しない。単純なグリカールである 17 の場合にも 


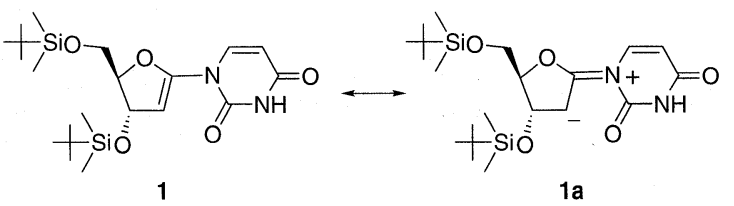

Fig. 5<smiles>Cc1cc(=O)[nH]c(=O)n1C1=CC(O[Si](C)(C)C)C(CO[Ge](C)(C)C)C1</smiles>

15

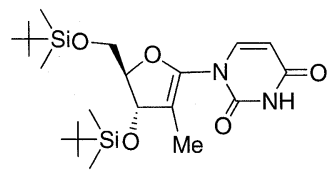

16<smiles>O=C(O)CC1OC=CC(Br)C1[Hg]Br</smiles>

Fig. 6

原料を回収するだけであった。

ここでは詳細については述べないが，この反応は塩基 部分がチミンやアデニンの場合にも進行し，付加体を高 収率で与える。また，これらの付加体からアノメリック ラジカルを発生させ，アクセプターと反応させることで 1'-炭素置換-2'-デオキシヌクレオシドを合成すること もできた。

\section{2', 3'-不飽和ヌクレオシドの化学変換}

\section{1 ヌクレオシド 2', 3'-芒ノールエステル: 求電子}

置換反応による 3 -炭素置換ヌクレオシドの合 成 ${ }^{10)}$

はじめでも述べたようにヌクレオシドの糖部分におけ
る炭素置換基の導入には，糖部カルボニル基に対する炭 素求核剤の 1,2-付加反応やWittig 反応が主として用い られ，炭素求電子剤を用いた反応例の報告はなかった。 そこで筆者らは，アルドール反応による $3^{\prime}$-炭素置換又 クレオシドの合成を計画した。塩基性条件下における $2^{\prime}$-ケトヌクレオシドの異性化を回避するために ${ }^{11)}$ ，そ の合成等価体であるエノールエステル 21 を用いること にした(スキーム3)。

ウリジン誘導体 18 にジフェニルジセレニドと水素化 ホウ素ナトリウムから調製したフェニルセレニドアニオ ンを反応させて $3^{\prime}-\beta$-フェニルセレニド 19 を得た。脱

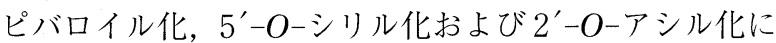
より 20 へと変換した。化合物 $20 \mathrm{a}$ を $m$-CPBA で処理 したところ，生成したセレノキシドのsyn-脱離は速や かに進行したが，精製中に加水分解を受け $2^{\prime}$ 一ケト体が 生成した。一方，20b からは目的とするエノールエステ ル 21 をほぼ定量的な収率で調製することができた。

メチルリチウムを用いて 21 からエノラートを発生さ せ，ベンズアルデヒド $/ \mathrm{BF}_{3} \cdot \mathrm{OEt}_{2}$ を反応させるとアル ドール付加物 22a が生成した。化合物 22a は容易に逆 アルドール反応を受けるために，“one-pot”で L-Selectride ${ }^{\mathrm{TM}}$ による還元を行い，引き続くアセチル化により 23 として単離した。また反応混合物をメシルクロリド で処理してエノン 24aとし，さらに1'位における異性 化を防ぐために, Luche 還元に付してアリルアセテート $25 \mathrm{a}$ へと変換した。一方，脂肪族アルデヒド(アセトア ルデヒド，イソブチルアルデヒド)を求電子剤として用 いると，生成する付加物 22b および 22c はシリカゲル

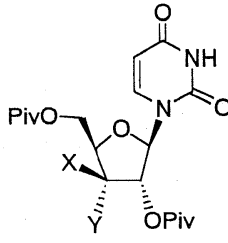

$18 X=H, Y=O M s$ $19 \mathrm{X}=\mathrm{SePh}, \mathrm{Y}=\mathrm{H}$

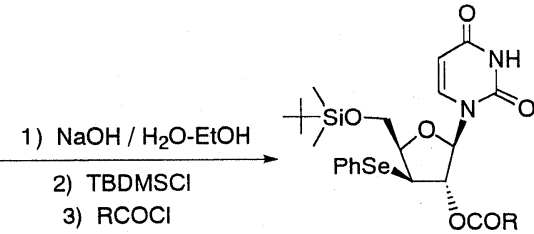

20a $\mathrm{R}=\mathrm{Me}$ 20b $R=E t$

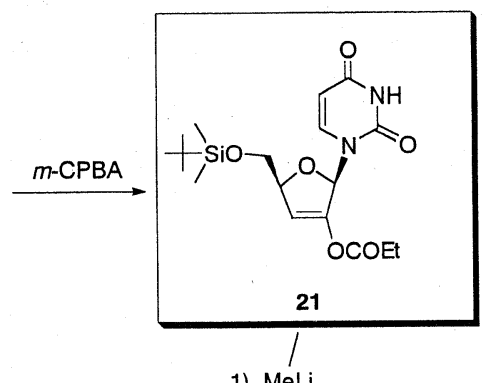
1) $\mathrm{MeLi}$ $\mathrm{RCHO} / \mathrm{BF}_{3} \cdot \mathrm{OEt}_{2}$

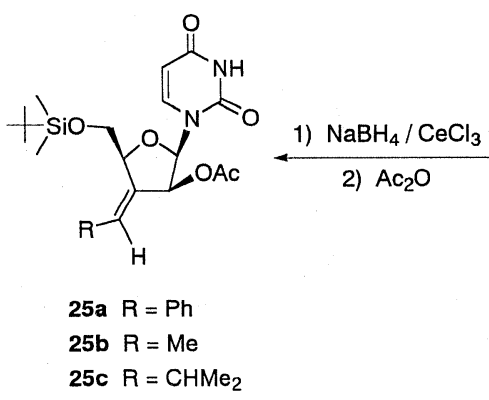<smiles>[H]/C=C1/C(=O)C(n2ccc(=O)[nH]c2=O)OC1CO[Ge](C)(C)C</smiles>

24a $\mathrm{R}=\mathrm{Ph}$

24b $R=M e$ 24c $\mathrm{R}=\mathrm{CHMe}_{2}$

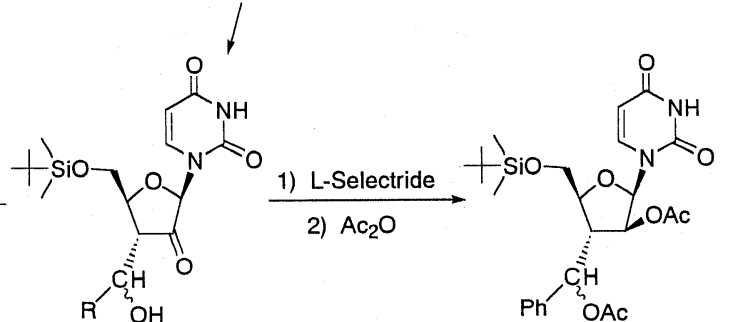

22a $R=P h$

22b $\mathrm{R}=\mathrm{Me}$

22c $\mathrm{R}=\mathrm{CHMe}_{2}$

Scheme 3 
カラムによる精製の段階で脱水が起こり, エノン 24b, $24 \mathrm{c}$ として単離された。各々をヒドリド還元ののち，ア セチル化によりアリルアセテート 25b および 25cを得 ることができた。

\section{2 ヌクレオシド 2', 3'-ビニルブロマイド: 2'- お} よび 3'-炭素置換 d4 ヌクレオシドの合成 ${ }^{12)}$

2', 3'-ジデヒドロ-3'-デオキシチミジン (d4 T, stavudine) は, ヌクレオシド系逆転写酵素阻害剂として臨床 で用いられているエイズ治療薬である ${ }^{13)}$ 。毒性の軽減や 耐性ウイルスに有効な化合物を見出すべく, 現在までに 種々の d 4 ヌクレオシド $(\mathrm{d} 4 \mathrm{Ns})$ 誘導体が合成されてい るが，2'-または $3^{\prime}$-炭素置換体の一般性のある合成法 は知られていなかった。ハロゲン化ビニルはパラジウム 触媒によるクロスカップリング反応ではビニルカチオン として, ハロゲンーリチウム交換反応ではビニルアニオ ンとして機能し炭素-炭素結合を構築できる。筆者らは ブロモビニル構造を有する $2^{\prime}, 3^{\prime}$-不飽和ヌクレオシド が，d 4 Ns の 2'位または $3^{\prime}$ 位に広範囲の炭素置換基を 導入するための有用な中間体になると考えた。そこで, セレノキシドの syn-脱離反応を利用するブロモビニル 体の合成とその炭素-炭素結合形成反応について検討 した。

筆者らは， $\beta$-ヒドロキシセレニド 26 の $2^{\prime}$ 位水酸基の 臭素化と引き続くセレノキシドの syn-脱離反応により, 目的とするブロモビニル体を合成できると考えた(ス キーム 4)。一般に $\beta$-ヒドロキシセレニドはトリエチル アミンの存在下, 塩化チオニルと反応させると脱離反応

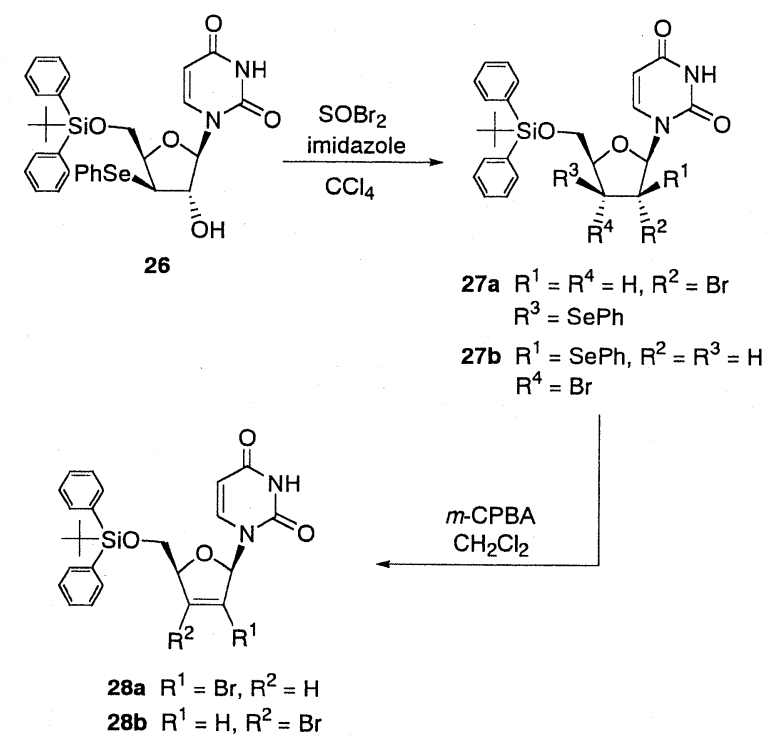

Scheme 4

が起こりアルケンを与えるが14)，この反応をアミンの非 存在下で行うと， $\beta$-クロロセレニドが得られることが 知られていた ${ }^{15)}$ 。そこで，26を四塩化炭素中，臭化于 オニルで処理したところ，生成する“2”, 3'-up”セレニラ
ニウム中間体を臭化物イオンが求核攻撃して，ブロモセ レニドの位置異性体 (27a, 27b) の混合物が 38\% の収率で 得られた。収率の改善を目的として, 反応時間や臭化于 オニルの当量数を検討したが良好な結果は得られなかっ た。一方, 上述した報告に反して, 反応系にトリエチル アミンを添加すると脱離反応は起こらず，26(10\%)を回 収するとともに 27 が56\%の収率で得られた。塩基とし てイミダゾールを用いたところ, 収率は $72 \%$ にまで向 上した。実際には，27の安定性に問題があったので， 臭素化反応の混合物を直ちに酸化して syn-脱離を行い, 28a 38\%，28bを 42\%の収率で合成した。この方法に よってアデニンヌクレオシド 29 からも，30aを $33 \%$, 30b を 41\%の収率で得た(図 7)。
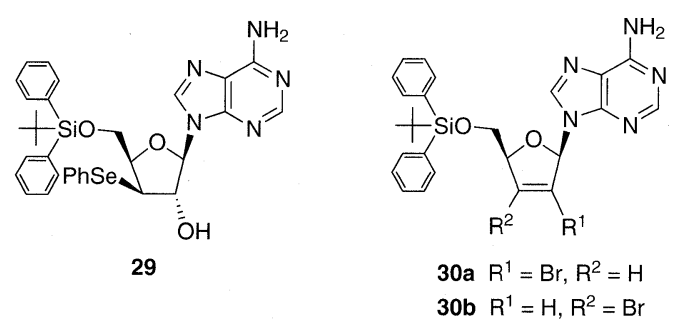

Fig. 7

パラジウム触媒を用いるクロスカップリング反応はヌ クレオシドの塩基部分の反応として繁用されていたが, 糖部分における炭素一炭素結合形成に用いられた例は皆 無であった。3’-ブロモビニル体 28b D DMF 中，トリ エチルアミンの存在下, 末端アセチレンとのSonogashira couplingに付したところ，3'-エチニル体 31a および31bを得ることができた(図 8)。Stilleらによっ

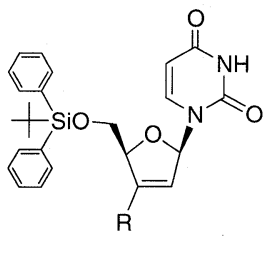

31a $\mathrm{R}=\mathrm{C} \equiv \mathrm{CPh}$

31b $\mathrm{R}=\mathrm{C} \equiv \mathrm{CSiMe}_{3}$

31c $\mathrm{R}=\mathrm{CH}=\mathrm{CH}_{2}$

31d $\mathrm{R}=\mathrm{Ph}$

31e $\mathrm{R}=\mathrm{Me}$

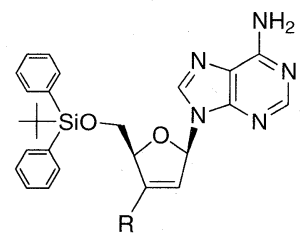

32a $\mathrm{R}=\mathrm{C} \equiv \mathrm{CPh}$ 32b $\mathrm{R}=\mathrm{C} \equiv \mathrm{CSiMe}_{3}$ 32c $\mathrm{R}=\mathrm{CH}=\mathrm{CH}_{2}$ 32d $\mathrm{R}=\mathrm{CH}_{2} \mathrm{CH}=\mathrm{CH}_{2}$

Fig. 8

て反応性が高いと報告されているトリブチルビニルスズ とのカップリングは比較的温和な条件下進行し, $\left(\mathrm{DMF} / 60{ }^{\circ} \mathrm{C} / 1 \mathrm{~h}\right), 3^{\prime}$-ビニル体 $(31 \mathrm{c})$ を与えた。これに

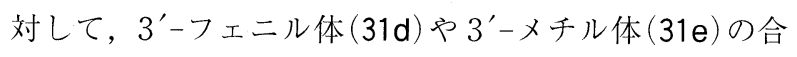
成に用いたテトラフェニルスズやテトラメチルスズとの 反応は極めて遅くジオキサン中, $100{ }^{\circ} \mathrm{C} て ゙ 1-2$ 日間の 加熱擋汼を要した。これらの反応をアデニンヌクレオシ ド30bに適用して 32a-d を合成したが, フェニルスズ ならびにメチルスズとの反応では対応する $3^{\prime}-$ 炭素置換 
体の生成は認められなかった。

つぎにハロゲンーリチウム交換反応を検討した。3'-ブ ロモビニル体 $28 \mathrm{~b}$ を 2 当量のブチルリチウムで処理し， 10 分後に 5 当量のベンズアルデヒドを加えたところ, 目的物である $33 \mathrm{~b}$ の生成は全く認められず, ウラシル とともに 55\%の脱ブロモ体 $33 \mathrm{a}$ が得られた。ウラシル の生成は $4^{\prime}$ 位の水素原子の引き抜きによる $\delta$-脱離の結 果と考えられることから, 塩基性の高いビニルリチウム 中間体が求電子剂を加える以前に $4^{\prime}$ 位水素原子によっ てプロトン化されるものと想定した。事実, リチウム化 の直後にベンズアルデヒドを加えると低収率 $(8 \%)$ なが らも33bを得ることができた。

そこで，あらかじめ $28 \mathrm{~b}$ とベンズアルデヒド (10 当 量)の THF 溶液を調製し, ブチルリチウムを徐々に滴 下していく“in situ trapping”法を採用したところ，3”炭素置換体 33b を $84 \%$ の収率で合成することができた (表 2)。この方法を用いると, 少量の 33a は副生するも のの，ウラシルの生成は完全に抑えることができた。ヨ ウ化メチルやイソブチルアルデヒドとの反応も, 33c な らびに33dを好収率で与えた。同様の方法を用いて， $2^{\prime}$-ブロモビニル体 $28 \mathrm{a}$ から $2^{\prime}$-炭素置換 $(33 e, 33 f)$ を合 成した。

\section{3', 4'-不飽和ヌクレオシドの化学変換}

面選択的 $\mathrm{S}_{\mathrm{N}} 2^{\prime}$ 反応による $4^{\prime}$-炭素置換 $\mathrm{d} 4$ ヌクレオシ ドの合成 ${ }^{16)}$

アリルアセテート構造を持つ $3^{\prime}, 4^{\prime}-$ 不飽和ヌクレオシ ド 34 を基質として，求核剤による $\mathrm{S}_{\mathrm{N}} 2^{\prime}$ 反応が可能なら ば $4^{\prime}$ 位における新規な炭素-炭素結合構築法を開発でき ると考えた。

ルイス酸として $\mathrm{BF}_{3} \cdot \mathrm{OEt}_{2}$ を用い，34とアリルトリ

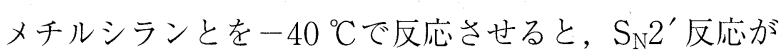
進行し目的とする $4^{\prime}-\alpha-$ アリル $-\mathrm{d} 4 \mathrm{U} 35 \mathrm{a}(33 \%)$ と, そ の立体異性体 35b(14\%) および脱離生成物 36(30\%) が得

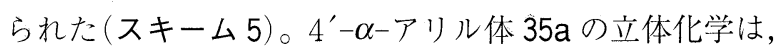
保護基のベンゼン環による磁気異方性効果によってウラ シル塩基 5 位のプロトンが高磁場シフトすることで確認 した。

添加するルイス酸を $\mathrm{SnCl}_{4}$ に変えると, 反応は -78 ${ }^{\circ} \mathrm{C}$ で完結し, 単離収率および面選択性 (35a: 74\%,

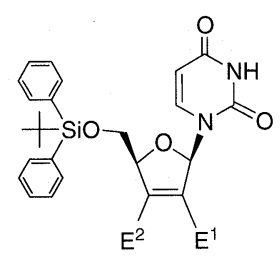

33a $E^{1}=E^{2}=H$

33b $E^{1}=\mathrm{H}, \mathrm{E}^{2}=\mathrm{CH}(\mathrm{OH}) \mathrm{Ph}$

33c $E^{1}=H, E^{2}=M e$

33d $E^{1}=\mathrm{H}, E^{2}=\mathrm{CH}(\mathrm{OH}) \mathrm{CHMe}_{2}$

33e $E^{1}=\mathrm{CH}(\mathrm{OH}) \mathrm{Ph}, \mathrm{E}^{2}=\mathrm{H}$

33f $E^{1}=M e, E^{2}=H$

Table 2 Halogen-lithium exchange reaction of $28 \mathrm{a}$ or $28 \mathrm{~b}$ by in situ trapping method.

\begin{tabular}{cccc}
\hline entry & substrate & electrophile & product (isolated yield) \\
\hline 1 & 28b & PhCHO & 33b (84\%) \\
2 & 28b & $\mathrm{Mel}$ & 33c $(53 \%)$ \\
3 & 28b & $\mathrm{Me}_{2} \mathrm{CHCHO}$ & 33d $(75 \%)$ \\
4 & 28a & $\mathrm{PhCHO}$ & 33e $(54 \%)$ \\
5 & 28a & $\mathrm{Mel}$ & $\mathbf{3 3 f}(38 \%)$ \\
\hline
\end{tabular}

35b: $5 \%)$ が大きく向上するとともに 36 の副生も抑える ことができた。図 9 には，他の有機シリコン試剤と 34 との反応の結果を示した。 $4^{\prime}-$ アセトニル体 37 および $4^{\prime}$-フェナシル体 38 は, 求核剂としてシリルエノール エーテルを用いて合成した。フェナシル体の合成の場合 には， $\mathrm{S}_{N} 2$ 反応も併発し $2^{\prime}$-置換体 40 が副生した。 $4^{\prime}-$ シアノ体 39 は, シアノトリメチルシランを用いて合成 した。

反応基質 34 では，脱離基であるアセトキシ基はフラ。 ノース環の $2^{\prime}$ 位 $\beta$ 側に位置していた。 $\alpha$ 側にアセトキ シ基を有するシトシンヌクレオシド 41 のアリル化もシ アノ化も $\mathrm{SnCl}_{4}$ の存在下 $-30{ }^{\circ} \mathrm{C}$ で進行し, $4^{\prime}-\alpha$-アリル 体 $(42 a)$ および $4^{\prime}-\alpha$-シアノ体 $(43 a)$ を主生成物として与 えた(図 10)。 $\mathrm{S}_{\mathrm{N}} 2^{\prime}$ 反応の立体化学に関して, 求核剤が 脱離基と同じ面から反応することはよく知られた事実で あるが，本反応の基質として用いた $3^{\prime}, 4^{\prime}-$ 不飽和ヌクレ オシドの場合には，脱離基の立体配置に関係なく $4^{\prime}$ 位 $\alpha$ 側からの求核攻撃が主として起こっていることになる。 この結果は，フラノース環内酸素原子の関与によるオキ ソニウム中間体の介在を示唆しているものと思われる。

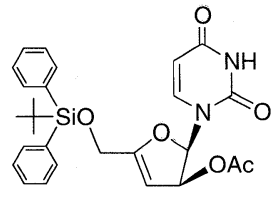

34

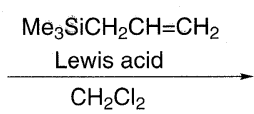

$\mathrm{CH}_{2} \mathrm{Cl}_{2}$

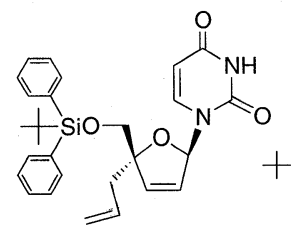

$35 a$

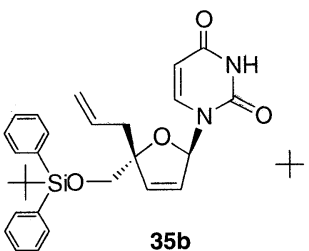

$35 b$

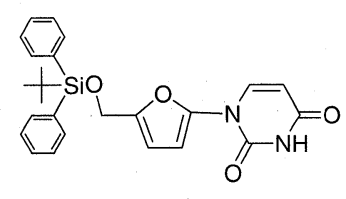

36

Scheme 5 


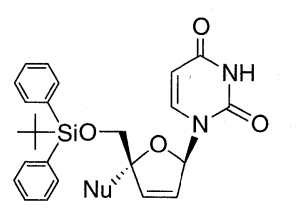

37a $\mathrm{Nu}=\mathrm{CH}_{2} \mathrm{COMe} \mathrm{(44 \% )}$ 38a $\mathrm{Nu}=\mathrm{CH}_{2} \mathrm{COPh}$ (55\%) 39a $\mathrm{Nu}=\mathrm{CN}(43 \%)$

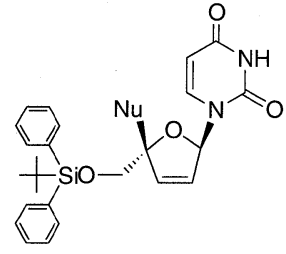

37b $\mathrm{Nu}=\mathrm{CH}_{2} \mathrm{COMe}(7 \%)$ 38b $\mathrm{Nu}=\mathrm{CH}_{2} \mathrm{COPh}(9 \%)$ $39 \mathrm{~b} \mathrm{Nu}=\mathrm{CN}(21 \%)$

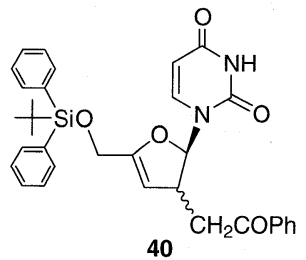

Fig. 9<smiles>CC(=O)Nc1ccn([C@@H]2OC(COC(C)C)=C[C@H]2OC(C)=O)c(=O)n1</smiles>

$$
41
$$<smiles>CC(=O)Nc1ccn([C@@H]2C=C[C@@](N)(COC(C)=O)O2)c(=O)n1</smiles>

42a $\mathrm{Nu}=\mathrm{CH}_{2} \mathrm{CH}=\mathrm{CH}_{2}(65 \%)$ 43a $\mathrm{Nu}=\mathrm{CN}(80 \%)$

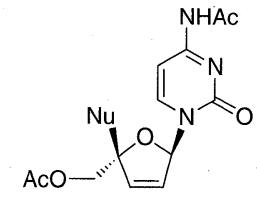

42b $\mathrm{Nu}=\mathrm{CH}_{2} \mathrm{CH}=\mathrm{CH}_{2}(15 \%)$ 43b $\mathrm{Nu}=\mathrm{CN}(10 \%)$

Fig. 10

\section{4. $4^{\prime}, 5^{\prime}$-不飽和ヌクレオシドの化学変換}

\section{1 ラジカル付加反応による $5^{\prime}$ 位での炭素鎖伸長 ${ }^{17}$}

$4^{\prime}, 5^{\prime}$-不飽和ヌクレオシドに対する炭素ラジカルの付 加反応よって，5'位に拈ける炭素鎖の伸長を行った。 $2^{\prime}, 3^{\prime}$ 位水酸基をイソプロピリデン保護した $44 \mathrm{a}$ と $\mathrm{PhCOSePh}$ をベンゼン中, $\mathrm{AIBN} / \mathrm{Bu}_{3} \mathrm{SnH}$ の共存下に 反応させたところ，ベンゾイルラジカルが5’位を攻撃 して生成する $4^{\prime}$-炭素ラジカルがウラシル塩基に 1,4-付 加した 45 が得られた(図 11)。一方，2'，3’位をシリル

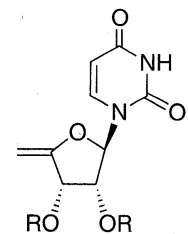

44a $\mathrm{R}-\mathrm{R}=$ isopropylidene 44b $R=$ tert-butyldimethylsilyl $44 c R=A c$ 44d $\mathrm{R}=\mathrm{H}$

Fig. 11
保護した 44b を基質に用いて本反応を行ったところ， 塩基部分に対する付加は全く起こらず $\alpha-\mathrm{L}-リ$ リソフラ ノシル誘導体 46a が単一の生成物として得られた(表 3)。 ラジカル前駆体として $\mathrm{PhSeCO}_{2} \mathrm{Et} や \mathrm{PhSeCH}_{2} \mathrm{CO}_{2} \mathrm{Et}$ を

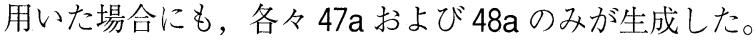

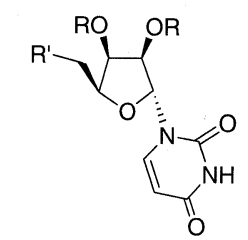

$\alpha$-L-lyxofuranosyl derivative

46a-48a $R=$ tert-butyldimethylsilyl

49a $R=A c$

50a-51a $\mathrm{R}=\mathrm{H}$

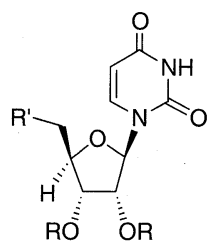

$\beta$-D-ribofuranosyl derivative

49b $R=A c$ 50b-51b $R=H$

Table 3 Radical addition reaction to $44 \mathrm{~b}-\mathrm{d}$.

\begin{tabular}{ccccc}
\hline entry & substrate & radical source & \multicolumn{1}{c}{$\mathrm{R}^{\prime}$} & product (isolated yield) \\
\hline 1 & $\mathbf{4 4 b}$ & $\mathrm{PhSeCOPh}$ & $\mathrm{COPh}$ & $\mathbf{4 6 a}(73 \%)$ \\
2 & $\mathbf{4 4 b}$ & $\mathrm{PhSeCO}_{2} \mathrm{Et}$ & $\mathrm{CO}_{2} \mathrm{Et}$ & $\mathbf{4 7 a}(55 \%)$ \\
3 & $\mathbf{4 4 b}$ & $\mathrm{PhSeCH}_{2} \mathrm{CO}_{2} \mathrm{Et}$ & $\mathrm{CH}_{2} \mathrm{CO}_{2} \mathrm{Et}$ & $\mathbf{4 8 a}(89 \%)$ \\
4 & $\mathbf{4 4 c}$ & $\mathrm{PhSeCO}_{2} \mathrm{Et}$ & $\mathrm{CO}_{2} \mathrm{Et}$ & $\mathbf{4 9 a}(37 \%), \mathbf{4 9 b}(28 \%)$ \\
5 & $\mathbf{4 4 d}$ & $\mathrm{PhSeCO}_{2} \mathrm{Et}$ & $\mathrm{CO}_{2} \mathrm{Et}$ & $\mathbf{5 0 a}(5 \%), \mathbf{5 0 b}(30 \%)$ \\
6 & 44d & $\mathrm{PhSeCH}_{2} \mathrm{CO}_{2} \mathrm{Et}$ & $\mathrm{CH}_{2} \mathrm{CO}_{2} \mathrm{Et}$ & $\mathbf{5 1 a}(7 \%), \mathbf{5 1 b}(45 \%)$ \\
\hline
\end{tabular}

これらの反応では立体的にかさ高いシリル基がフラ ノース環の $\alpha$ 面を遮蔽しているために，中間体として 生成する $4^{\prime}-$ ラジカルがもっぱら $\beta$ 面で $\mathrm{Bu}_{3} \mathrm{SnH}$ と反応 したものと考えられる。比較的立体障害の小さなアセチ ル基で保護した基質 $44 \mathrm{c}$ と $\mathrm{PhSeCO}_{2} \mathrm{Et}$ のラジカル反応 では，49a とともに $\beta$-D-リボフラノシル体 $49 \mathrm{~b}$ が得ら れた。 $\beta$-Dーリボヌクレオシドの生成比を改善する目的 で，遊離のヌクレオシド44d を基質として用いた。こ の場合，溶解度の問題でベンゼンは使用できないが $\mathrm{DMF}$ 中, $60-70{ }^{\circ} \mathrm{C}$ で $\mathrm{PhSeCO}_{2} \mathrm{Et}$ および $\mathrm{PhCH}_{2} \mathrm{CO}_{2} \mathrm{Et}$ との反応を行ったところ, 望みの立体化学を有する50b および51bが主生成物となった。

$2^{\prime}$ 位水酸基を欠く $4^{\prime}, 5^{\prime}$-不飽和チミジン 52(図 12)を 用いて $\mathrm{PhSeCO}_{2} \mathrm{Et}$ との反応を行ったところ， $4^{\prime}$-炭素 ラジカルによる $\mathrm{Bu}_{3} \mathrm{SnH}$ からの水素原子引き抜きが $\alpha$ 面からも $\beta$ 面からもほぼ均等に起こり，53a と 53b がそ れぞれ $27 \%, 29 \%$ の収率で生成した。従って, 先に述 ベた $4^{\prime}, 5^{\prime}$ 一不飽和ウリジン $44 \mathrm{~b}$ の反応で $\alpha$ 面が遮蔽さ れたのは，2’位シリル基の3’位シリル基に対する“支柱 効果 (buttressing effect)”よるものと考えられる。3’位 $\beta$ 側にアセトキシ基を配置した 54 を用いると，55のみ が $79 \%$ の収率で生成する。 

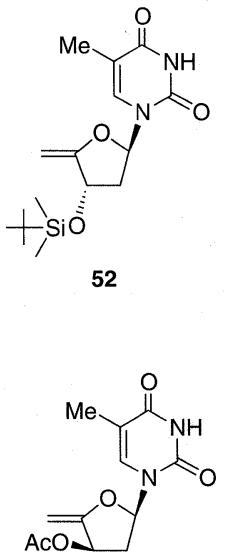

54

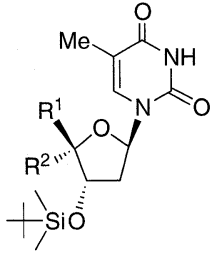

53a $\mathrm{R}^{1}=\mathrm{CH}_{2} \mathrm{CO}_{2} \mathrm{Et}, \mathrm{R}^{2}=\mathrm{H}$ 53b $R^{1}=\mathrm{H}, \mathrm{R}^{2}=\mathrm{CH}_{2} \mathrm{CO}_{2} \mathrm{E}$

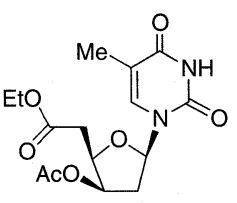

55

Fig. 12

\section{$4.24^{\prime}, 5^{\prime}$-エポキシヌクレオシドの求核的開環反応}

\section{による 4'-炭素置換ヌクレオシドの合成 ${ }^{18)}$}

AZT (zidovudine)やd 4 T (stavudine) (図 13)を代表例 とするヌクレオシド系エイズ治療薬は，3'位の水酸基 が欠如しているためにチェインターミネーターとして働 きHIVの逆転写を阻害する ${ }^{13)}$ 。比較的最近になって 4'-シアノチミジン (56)や 4’-アジドチミジン (57)が, $\mathrm{AZT}$ よりも強力な抗 HIV 活性を示すことが報告され た。 $3^{\prime}$ 位水酸基を有するこれらの化合物は，既存の又 クレオシド系エイズ治療薬とは異なる作用機序で活性を 発現している可能性があり，注目を集めている。また， 4'-アジドチミジンの 3'位水酸基を欠く 58 や 59 が全く 活性を示さないとの報告から，「4'位置換ヌクレオシド が抗 HIV 活性を示すためには，3’位水酸基の存在が必 須である」というのが定説になっている。

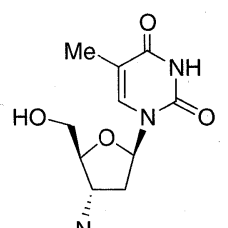

$\overline{\mathrm{N}}_{3}$ AZT (zidovudine)

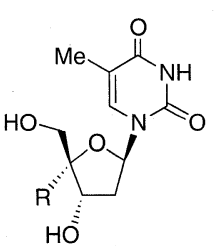

$56 \mathrm{R}=\mathrm{CN}$

$57 \mathrm{R}=\mathrm{N}_{3}$

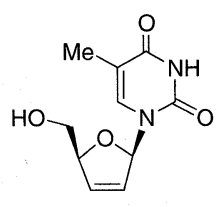

d4T (stavudine)

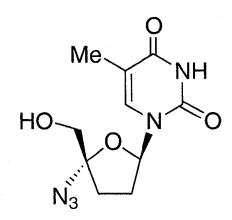

58

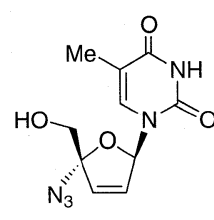

59
Fig. 13

ヌクレオシドの $4^{\prime}$ 位に炭素置換基を導入するために は，ヌクレオシド5'-アルデヒドの aldol-Cannizzaro 反 応により得られる $4^{\prime}$-ヒドロキシメチル体を化学変換す
る手法が主として用いられてきた。筆者らは，4', $5^{\prime}$-不 飽和ヌクレオシドをエポキシドへ導き，炭素求核剤に よって開環する $4^{\prime}$-炭素置換体の合成経路を立案した。 エノールエーテル構造を有する $4^{\prime}, 5^{\prime}$-不飽和ヌクレオシ ドは，酸性条件下で容易に求核試剤の攻撃を受けると考 えられる。そこで, 中性条件下, 非プロトン性溶媒中で 使用できる酸化剛としてジメチルジオキシラン (DMDO) を選択した。

4', 5'不飽和ウリジン 44b を塩化メチレン中, DMDO による酸化に付したところ $4^{\prime}, 5^{\prime}-$ エポキシド 60 を単一 の立体異性体として与えた (スキーム 6)。化合物 60 と

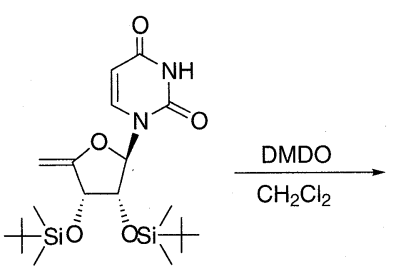

$44 b$

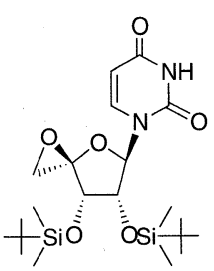

60
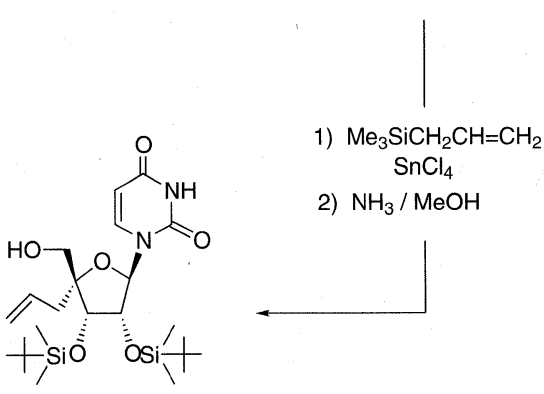

61

\section{Scheme 6}

アリルトリメチルシランとを $\mathrm{SnCl}_{4}$ の存在下に反応させ ると, メタノール性アンモニアによる処理ののち, 目的

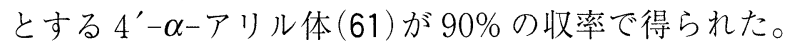
この反応を精査した結果，いくつかの中間体を単離する ことができ，スキーム7の反応機構を想定するに至った。

エポキシドの開環によって 4'-クロロ体 $62 \mathrm{a}$ および $62 \mathrm{~b}$ が生成するが, 脱離基となるクロル原子が pseudo-axial 結合である 62a では, 求核置換反応が円滑 に進行しスピロ中間体 63 を与える。一方, 塩素原子が pseudo-equatorial 結合となっている 62b では, 求核置 換反応が不利であるとともにウラシル塩基の立体障害に より求核剂の接近が妨げられる。従って，62b はオキソ ニウムイオンCを経て $62 \mathrm{a}$ へ異性化したのち 63 を与え る。スピロ体 63 は, トリメチルシリルクロリドの脱離

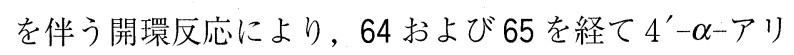
ル体 (61)を与えるものと考えている。

エポキシドを経由するアリルトリメチルシランとの反

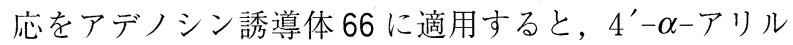
アデノシン $67(52 \%)$ を，チミジン誘導体 68 からは 69 (80\%)を合成することができた(図 14)。 

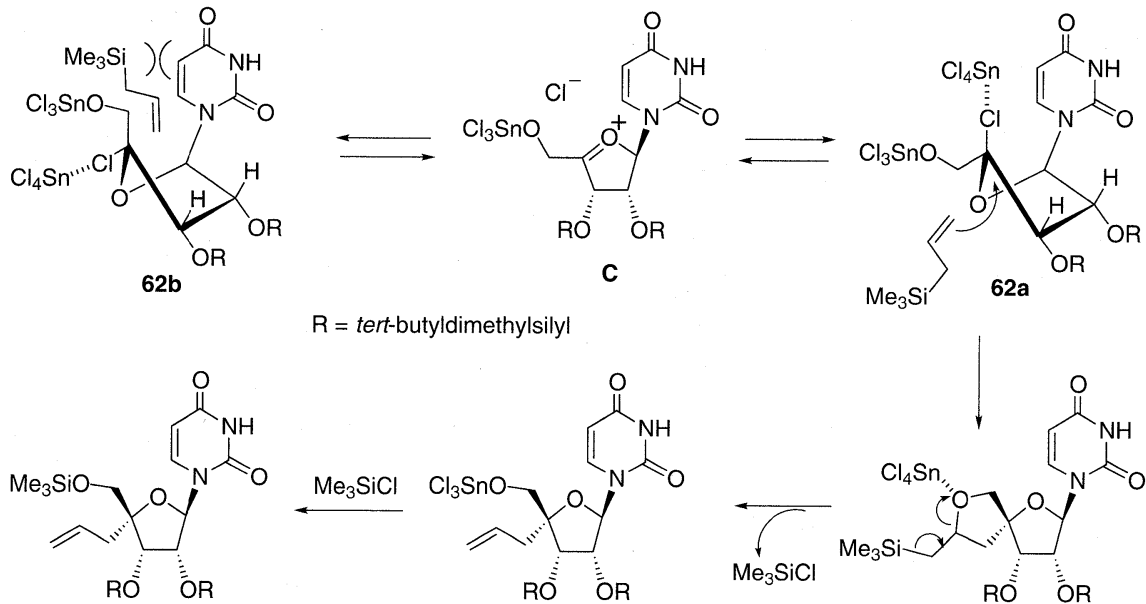

65

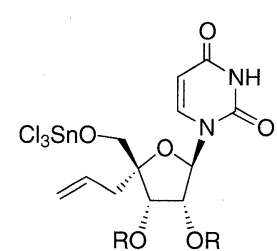

64

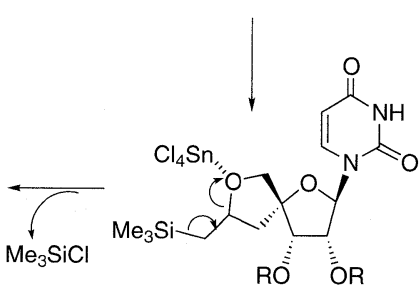

63

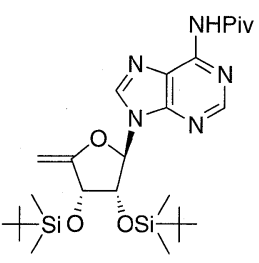

66

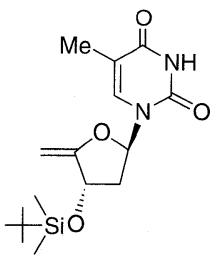

68

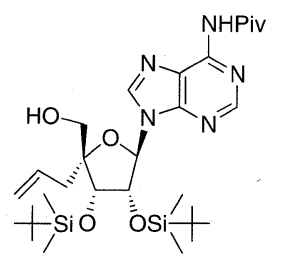

67

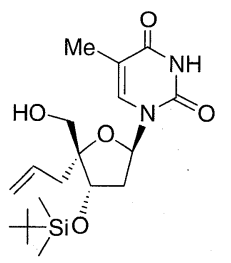

69
Fig. 14

4', 5'-不飽和チミジン 68 から調製したエポキシドと トリメチルアルミニウムとの反応では，アリルシランの 場合とは異なり，主成績体は $4^{\prime}-\beta$-メチル体 70b (64\%) であり $4^{\prime}-\alpha$-メチル体 70a の収率はわずかに $5 \%$ であっ た(図 15)。この反応では，エポキシドの開裂により生 成するオキソニウムイオンがスキーム 8 に示すDと E と の平衡状態となり， 5’-アルミネートと $3^{\prime}$ 位のシリル基 との間に，立体反発を生じないコンホマーEからの求 核攻撃が優先して起こるものと想定した。そこで，3’位 $\beta$ 側にシリルオキシ基を配置した 71 のエポキシ化と各 種有機アルミニウム試剤との反応を行った。その結果, $\alpha$ 側から炭素求核剤が攻撃した $4^{\prime}-\alpha$-炭素置換体 72-74 を立体選択的に得ることができた(図 15)。

得られた 72-74を用い，5'位のアセチル化，脱シリ ル化, メシル化, メシル酸の脱離を経由してd4 T の 4'-炭素置換体である 75-77へ誘導した(図 16)。これ

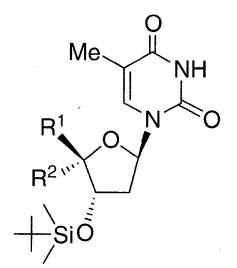

70a $\mathrm{R}^{1}=\mathrm{CH}_{2} \mathrm{OH}, \mathrm{R}^{2}=\mathrm{Me}$ 70b $\mathrm{R}^{1}=\mathrm{Me}, \mathrm{R}^{2}=\mathrm{CH}_{2} \mathrm{OH}$
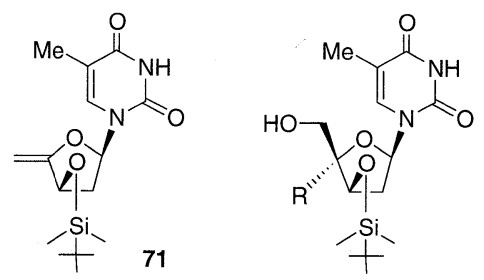

$72 \mathrm{R}=\mathrm{Me}$

$73 \mathrm{R}=\mathrm{CH}=\mathrm{CH}_{2}$ $74 \mathrm{R}=\mathrm{C} \equiv \mathrm{CH}$

Fig. 15<smiles>[R]c1cn(C2C=C[C@H]([2H])O2)c(=O)[nH]c1=O</smiles>

$75 \mathrm{R}=\mathrm{Me}$

$76 \mathrm{R}=\mathrm{CH}=\mathrm{CH}_{2}$ $77 \mathrm{R}=\mathrm{C} \equiv \mathrm{CH}$

Fig. 16

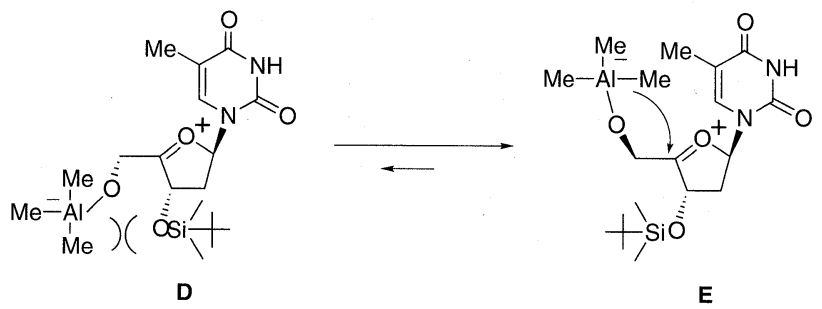

Scheme 8

らの化合物の抗 HIV 活性を調ベたところ， $4^{\prime}$-エチニル

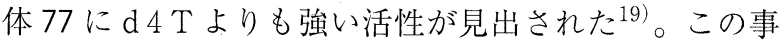
実は，先に述べた「4'位置換ヌクレオシドが抗 HIV 活性 を示すためには，3'位水酸基の存在が必須である」とい う定説を覆すものである。化合物 77 は，宿主細胞に対 
する毒性も, 正常細胞に対する毒性の指標となるミトコ

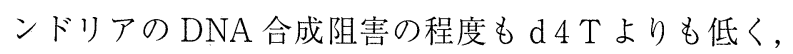
新規エイズ治療薬の開発におけるリード化合物となるこ とが期待される。

\section{おわりに}

これまでヌクレオシドの合成化学において注目される ことのなかった不飽和糖ヌクレオシドを利用して, 糖部 分における新規な炭素-炭素結合反応についての研究を 進めてきた。まだ問題は山積しているが，ともかくヌク レオシド糖部分のすべての位置に炭素置換基を導入でき るようになった。なかでも, ヌクレオシドレベルの反応 では困難であった $1^{\prime}$-および $4^{\prime}$-炭素置換体の合成に関 する研究では, ヌクレオシド化学のおもしろさを満喫で きた。今後は, これらの合成方法を適用して, 新しい機 能を持つヌクレオシド誘導体を創製できればと考えて いる。

謝 辞 本稿で紹介した研究の成果は, 昭和大学薬学 部・薬品製造化学教室に在籍した多くの学部学生, 大学 院生の熱意とたゆまぬ努力の結晶であり，共同研究者と して心から感謝の意を表します。また，本研究を遂行す るにあたりご助言をいただきました宮坂貞名誉教授に感 謝いたします。本研究の一部は文部科学省および日本学 術振興会 (科学研究費補助金), 上原記念生命科学財団, ならびに薬学研究奨励財団からのご援助により行われた ものであり，記してお礼申し上げます。

(2003 年 5 月 12 日受理)

\section{文 献}

1) (a) A. Matsuda, J. Synth. Org. Chem., Jpn., 48, 907 (1990); (b) E. Ichikawa, K. Kato, ibid., 59, 331 (2001)

2) K. Haraguchi, H. Tanaka, H. Maeda, Y. Itoh, S. Saito, T. Miyasaka, J. Org. Chem., 56, 5401 (1991)

3) H. Kumamoto, H. Tanaka, J. Synth. Org. Chem., Jpn., 60, $145(2002)$

4) (a) K. Haraguchi, Y. Itoh, H. Tanaka, T. Miyasaka, Tetrahedron Lett., 34, 6913 (1993); (b) Y. Itoh, K. Haraguchi, H. Tanaka, E. Gen, T. Miyasaka, J. Org. Chem., 60, 656 (1995)

5) (a) H. Yüntsen, H. Yonehara, H. Vi, J. Antibiot. Ser. A., 7, 113 (1954); (b) H. Yüntsen, K. Ohkuma, Y. Ishii, ibid., 9, 195 (1956); (c) W. Schroeder, H. Hoeksema, J. Am. Chem. Soc., 81, 1767 (1959); (d) J. R. McCarthy, R. K. Robins, M. J. Robins, ibid., 90, 4993 (1968)

6) (a) Y. Itoh, K. Haraguchi, H. Tanaka, K. Matsumoto, K. T. Nakamura, T. Miyasaka, Tetrahedron Lett., 36, 3867 (1995); (b) K. Haraguchi, Y. Itoh, K. Matsumoto, K. Hashimoto, K. T. Nakamura, H. Tanaka, J. Org. Chem., 68, 2006 (2003)

7) H. Kumamoto, M. Murasaki, K. Haraguchi, A. Anamura, H. Tanaka, J. Org. Chem., 67, 6124 (2002)
8) (a) J.-T. Hwang, M. M. Greenberg, J. Am. Chem. Soc., 121, 4311 (1999); (b) C. Chatgilialoglu, C. Ferreri, R. Bazzanini, M. Buerra, S.-Y. Choi, C. J. Emanuel, J. H. Horner, M. Newcomb, ibid., 122, 9525 (2000)

9) W. E. Parham, D. M. DeLaitsch, J. Am. Chem. Soc., 76, 4962 (1954)

10) K. Haraguchi, H. Tanaka, Y. Itoh, T. Miyasaka, Tetrahedron Lett., 32, 777 (1991)

11) (a) M. Kawana, K. Takeuchi, T. Ohba, H. Kuzuhara, Nucleic Acids Research Symposium Series, 17, 37 (1986); (b) K. Minamoto, N. Fujiwara, Y. Hamano, S. Eguchi, Nucleic Acids Symposium Series, 21, 121 (1989)

12) (a) K. Haraguchi, Y. Itoh, H. Tanaka, T. Miyasaka, Tetrahedron Lett., 32, 3391 (1991); (b) K. Haraguchi, Y. Itoh, H. Tanaka, M. Akita, T. Miyasaka, Tetrahedron, 49, 1371 (1991)

13) E. De Clercq, Acquired Immune Defic. Syndr., 4, 207 (1991)

14) (a) J. Remion, A. Krief, Tetrahedron Lett., 1976, 3743; (b) G. Wrensford, L. A. Grab, J. M. Salvino, P. G. Williard, ibid., 31, 4257 (1990)

15) A. Krief, Tetrahedron, 36, 2531 (1980)

16) (a) K. Haraguchi, H. Tanaka, Y. Itoh, S. Saito, T. Miyasaka, Tetrahedron Lett., 33, 2841 (1992); (b) K. Haraguchi, H. Tanaka, Y. Itoh, K. Yamaguchi, T. Miyasaka, J. Org. Chem., 61, 851 (1996)

17) K. Haraguchi, H. Tanaka, T. Miyasaka, Tetrahedron Lett., 31, 227 (1990)

18) K. Haraguchi, S. Takeda, H. Tanaka, Org. Lett., 5, 1399 (2003)

19) K. Haraguchi, S. Takeda, H. Tanaka, T. Nitanda, M. Baba, Y.-C. Cheng, Bioorg. Mrd. Chem. Lett. 印刷中

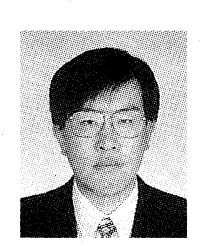

伊藤佳治 日本たばこ産業(株)医薬総合研究 所・研究員 博士(薬学)

〔経歴〕1994 年昭和大学薬学部大学院薬学研 究科博士後期課程修了, 同年鳥居薬品(株) 研究員, 1999 年より現職。〔専門〕有機合成 化学

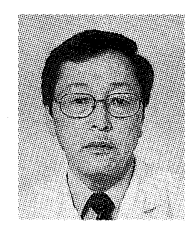

田中博道 昭和大学薬学部 薬品製造化学・ 教授 博士(薬学)

〔経歴〕1971 年北海道大学大学院薬学研究科 修士課程修了, 第一製薬(株) 研究員, 北海道 大学薬学部助手, 東京医科歯科大学専攻生を 経て 1979 年昭和大学薬学部講師, 1981 年同 助教授, 1998 年より現職。【専門〕核酸有機 化学 